Science, Technology and Development 35 (1): 1-5, 2016

ISSN 0254-6418 / DOI: 10.3923/std.2016.1.5

(C) 2016 Pakistan Council for Science and Technology

\title{
Catastrophe of Flood 2010 at Taunsa Barrage; Review of Technical Findings of Punjab Judicial Tribunal Report
}

\author{
${ }^{1}$ Zulfiqar Ali Chaudary and ${ }^{2}$ Muhammad Kaleem Sarwar \\ ${ }^{1}$ Department of Civil Engineering, Engineering University, Lahore, Pakistan \\ ${ }^{2}$ Centre of Excellence in Water Resources Engineering, Engineering University, Lahore, Pakistan
}

\begin{abstract}
In the year 2010, high intensity and continuous rainfall in the upper catchment of Indus River resulted exceptionally high flood in Punjab at Jinnah, Chashma and Taunsa Barrages. This unprecedented flood passed through Jinnah Barrage with some damages to its Left Guide Bank and with a control breach in its Right Guide Bank; whereas at Chashma barrage the flood passed safely. The flood could not pass Taunsa barrage and its Left Marginal Bund (LMB) collapsed; which resulted in more than 125,000 cusec of roaring flood towards human settlement of District Muzaffar Garh. The Punjab Judicial Tribunal investigated this human tragedy and recommended some serious penalties to those responsible. This research paper critically reviews the Tribunal's findings regarding the collapse of LMB of Taunsa Barrage.
\end{abstract}

Key words: Taunsa barrage, tribunal, flood 2010, LMB, sub-weir

\section{INTRODUCTION}

In Pakistan, the Punjab province is blessed with six large rivers (Indus, Jhelum, Chenab, Ravi, Sutlej and Beas), which caused massive flooding during rainy season, normally in summer months. As per Indus Water Treaty signed between India and Pakistan, the water rights of three eastern rivers (Ravi, Sutlej and Beas) are given to India, so there is less likelihood of high floods as India has constructed large reservoirs on these rivers. There is still a possibility of high floods in western rivers (Indus, Jhelum and Chenab) as the water storage capacity developed so far is very limited.

The Flood Year 2010, in Indus River, was the worst in the history of Indo-Pak region. The flood duration at Jinnah Barrage was more than three weeks, whereas the peak crossed the design discharge of the barrage. This unprecedented flood passed through Jinnah Barrage with some damages to its Left Guide Bank and its Right Guide Bank was blown up by the Authority, whereas, the flood passed safely at Chashma barrage, without causing any damage. This relentless flood could not pass through Taunsa barrage and its Left Marginal Bund (LMB) collapsed. District Muzaffar Garh was the most unfortunate area, where this massive flood through breached section caused catastrophe and drowned/destroyed human life, infrastructure, etc. The mighty Indus got derailed, it followed its own course through human habitation brutally displacing people and their livestock, besides damaging crops, buildings and the infrastructure.

The Punjab Judicial Tribunal investigated this human tragedy and recommended some serious penalties to these responsible. The Tribunal noted that in the past "The loss of life and property associated with floods have been colossal. In the year 1973, more than 3 million houses were destroyed and 160 persons lost their lives. The 1976 flood demolished over 10 million houses while 425 lives were lost with losses amounting to Rs. 6 billion. In 1988, an unprecedented flood occurred, inflicting Rs. 17 billion worth of damage to the country. The super flood of 1992 crossed all previous records with the damage estimated at Rs. 50 billion. Therefore, the Tribunal's findings may be important to minimize flood damages in future.

Although, flood 2010 was exceptionally high and of long duration, however, it was well within the discharge capacity of Taunsa barrage. The rules and regulation for maintenance and working of Taunsa Barrage in 1979, noted that, maximum discharge for which the barrage is designed is $10,00,000$ cusec, but it can take and pass a super-flood of 12,60,000 cusec safely (PID, 2007; Chaudary, 2009a, b; 2010c). It is to be noted that the LMB collapsed just at the discharge of 880,000 cusec on Aug 2, 2010 at about $16.00 \mathrm{~h}$. The Tribunal emphasized that the operational staff should be the driving force to pass flood safely. They noted that flustered, inexperienced and ill equipped flood managers fought a loosing battle. The Tribunal ignored/overlooked that the discharge capacity of Taunsa barrage may be compromised, due to the $8 \mathrm{ft}$ high sub-weir constructed during 2005-08, just in front of the barrage on its downstream, across the entire width and the leftover material of coffer dams (Chaudary, 2010a-c).

Corresponding Author: Muhammad Kaleem Sarwar, Centre of Excellence in Water Resources Engineering, Engineering University, Lahore, Pakistan 
It is still unclear that a barrage having $8 \mathrm{ft}$ high sub-weir/wall on its downstream side and leftover material of coffer dams may have the same discharge capacity. Flood affectees and private complainants submitted that there was a head up on upstream of the barrage; resulting in increased pressure and consequently a collapse of LMB. However, the Tribunal Report is silent regarding this very important fact that the head up may be due to the sub-weir and leftover material of the coffer dams, which is still lying downstream of the barrage.

This research is focused on determination of actual discharge and water level upstream of the barrage during flood 2010 and this may help to establish the reasons for head up, especially on left side of the barrage.

\section{RELEVANT STATEMENTS OF FLOOD AFFECTEES/PRIVATE COMPLAINANTS}

Flood affectees/private complainants submitted that there was a head up on upstream of the barrage. The statements submitted to the Tribunal are given as under:

- $\quad$ There was head up due to the closure of side gates of Taunsa barrage, which resulted in the breach of LMB. Out of 64 gates, 11 middle gates of the Barrage were closed prior to Aug 2, 2010 and in addition four gates on the right side and four gates on the left side were also closed, resulting in the raising of the pond level"

- "In order to save Spur No. 5, six gates on the left side of the barrage were closed on Jul 28, 2010 and remained closed till the time of breach"

- "In order to save forest in the Active Flood Plain, gates of the barrage were closed to build a head up so that the velocity of water passing through the forest does not damage it"

- "The gates of barrage were not opened in order to save the sub-weir downstream, which costed around Rs.11 billion to construct"

- "If officers of Irrigation Department timely opened the gates of barrage and ejected silt, there was no chance for the breach of LBM"

- "There was seepage in the LMB, which was pointed out by the local residents but no action was taken by the Irrigation Department. Seepage took place on the LMB, starting from Jul 26, 2010. No flood protection work was carried out by the Irrigation Department to protect the bund or plug the seepage taking place”

\section{MAJOR BREACHES}

The main breaches and their cause as reported in Judicial Flood Inquiry Tribunal (2010) are given in Table 1. It is noted that the flood from LMB is responsible for the breaches in Sanawan Bund and TP Link Canal.

Causes of LMB breach established by judicial tribunal: The Tribunal after considering complaints/evidences on record, reports of local commissions, local politicians and field survey, discussed the cause of breaches as under:

- $\quad$ Pre-flood preparedness

- Flood forecasting

- Flood fighting

- Technical cause of breach

- Political intervention

- Encroachment of pond area

- Role of PMO Punjab Barrages

However, as stated above, this research focuses on review of the technical cause of the breach in LMB.

\section{Breach in LMB: Positions of concerned authorities/ departments}

Position of secretary irrigation punjab: The Secretary Irrigation submitted that LMB breached at RD 32 to 33 around 4 p.m. on Aug 2, 2010, when the discharge in the River Indus was approaching 1.085 million cusecs. Hourly hydrograph from Aug 1-5, 2010 has been prepared which depicts high intensities and long duration of the discharges ever seen. The design capacity of the LMB was 1.0 million cusec with free board $6 \mathrm{ft}$ above HFL. The breach speedily developed to $1000 \mathrm{ft}$ and 125000 cusec discharge diverted, which after breaching banks of Taunsa Panjnad Link Canal and Muzaffar Garh Canal, flooded a vast area in District Muzaffar Garh.

Position of head PMO barrages: The earthen embankment did not leak or fail anywhere. So much so, no seepage at the toe was seen through earthen bund although the freeboard was badly encroached. Leakage did take place only in stone pitched portion (RD 32+000$34+500$ ). The bund failed in stone pitched portion by sudden collapse. It has been determined that failure of LMB was due to seepage. The embankment was not overtopped and there was a freeboard of $4.5 \mathrm{ft}$ when it breached. Similarly, no slope collapsed anywhere and structural failure is also ruled out.

Table 1: Location and cause of breaches (Judicial Flood Inquiry Tribunal, 2010)

\begin{tabular}{llll}
\hline S. No & Location & Date & Cause of breach \\
\hline LMB-B1 & RD-32-33, 34-40 & 02-08-10 & $\begin{array}{l}\text { At super flood, deep sheet flow took place and it was extraordinary headed up due to pocketing } \\
\text { effect of the four long spurs (RD 9, 11, 15, 26) and convex nature of LBM. Heading up continued } \\
\text { rapidly till the LMB breached due to foundation/HGL failure }\end{array}$ \\
SN-B2 Sanawan flood bund & 03-08-10 & Hitting of more than 125,000 cusecs discharge from breach at LBM
\end{tabular}


At about 4 PM on Aug 2, 2010, the water level speedily rose and the freeboard, which was kept originally $6.0 \mathrm{ft}$ above highest flood level of 1992, reduced to $4.5 \mathrm{ft}$., suddenly intense bubbling started on right prism side of the adjacent channel (Tibba Minor). When the discharge in the river reached 10.85 lac cusecs, the hydraulic gradient still remained covered all along and there would have been no chance of breach, as also experienced in un-pitched reaches of the bund. The Head PMO also conceded that the design of LMB was faulty and the presence of Tibba Minor alongside LMB was not considered in the actual design; however, in written statement, he changed the stance.

Position of Irrigation Research Institute (IRI), Punjab: It is apprehended that the breach of LMB occurred owing to the hole under stone pitching, which remained un-attended. The inspection of such important structures is carried out after June of each year for catering of any alarming situation and is tackled before commencement of flood season.

\section{FINDINGS OF THE JUDICIAL TRIBUNAL}

UET commission report: The first breach was triggered at 4 PM on Aug 2, 2010, which caused a parallel flow to the LMB resulting in another breach in the un-pitched portion at $10 \mathrm{PM}$ on the same day between RD 34+500 and 39+000. Maximum flood level at the time of breach was about RL $459 \mathrm{ft}$, whereas, the RL of top of the stone pitching is $463.21 \mathrm{ft}$, which means a free board of about $4 \mathrm{ft}$ was available.

The cross-section of LMB at pitched portion was in line with Federal Flood Commission (FFC) standard. According to FFC standards, the cross-section of bund should satisfy hydraulic gradient of 1:6, whereas the pitched section of LMB fulfills this requirement.

Gate opening of taunsa barrage: On August 02, 2010, the upstream discharge at 06:00 a.m. was 798,601 cusecs, which rose to 898,414 cusecs at 12:00 a.m. and continued to be the same till 7:00 p.m. and then suddenly at 8:00 p.m. a discharge of 959,177 cusecs was recorded in the Flood Register. According to the Flood Register, the breach took place at 4:00 $\mathrm{pm}$ and records a discharge of 125,000 cusecs from the said breach.

Flood Register shows that the discharge from the breach has no effect on the discharge from the Barrage which remains intact at $8,98,414$ cusecs. The recorded data also shows that as upstream discharge rose from 8 , 98,414 cusecs to 9, 59,177 cusecs at 8:00 p.m. till 11:00 p.m. and was finally reduced at 12.00 p.m. to 934,116 cusecs. The pond level, however, remained static at RL 446.80 from 9:00 am till 7:00 pm and from 8:00 p.m. till
11:00 p.m., the pond level was slightly reduced to RL 446.60 and at 12:00 pm it was recorded as RL 446.40.

It is not clear how the discharge at the breach was calculated to be 125,000 cusecs and why it had no effect on the discharge at the barrage. The figure of 125,000 cusecs does not inspire the confidence.

Overwriting in the flood register, as well as, the discharge recorded in the Daily Log Book on Aug 2, 2010 was 798,601 cusecs, while the discharge on Aug 3, 2010 was 767,351 cusecs; therefore, we are of the view that the discharge recorded as 959,177 cusecs at 8:00 pm on 02-08-2010 was not credible and appeared to be inflated just to match with the design capacity of the Barrage $(959177+125,000=1,084,177)$.

Tribunal's conclusion: A portion of LMB runs alongside Tibba Minor (RD 32-44), while designing and rehabilitating LMB, this aspect and the fact that LMB sits on an old creek was not considered. The design criterion of the FFC has been followed to the extent of Hydraulic Gradient being in the ratio of 1:6. The department miserably failed to comply with the other design requirement given in the FFC design criteria manual as well as in the National Flood Protection Plan, 1978.

\section{REVIEW OF COMPLAINTS/EVIDENCES}

Flood affectees/private complainants submitted that there was a head up in water level upstream of the barrage. "The Head PMO Barrages submitted that the freeboard was badly encroached and at about 4:00 pm on Aug 2, 2010, the water level rose speedily, the freeboard, which was kept originally $6.0 \mathrm{ft}$. above the highest flood level of 1992, reduced to $4.5 \mathrm{ft}$; suddenly the intense bubbling started and LMB collapsed". At super flood, deep sheet flow took place and it was extraordinarily headed up due to pocketing effect of the four long spurs (RD 9, 11, 15, 26) and convex nature of LBM. Heading up continued rapidly till the LMB breached due to foundation/HGL failure (Judicial Flood Inquiry Tribunal, 2010). It is apparent that there was an extraordinary rise in water level, consequently collapsing LMB.

It is to be noted that the discharge at the time of breach was just 798,414 cusecs instead of 1085,000 cusecs as reported by the Secretary Irrigation; whereas this barrage before the construction of sub-weir could pass 1,260,000 cusec safely (PID, 2007). The position of Secretary Irrigation that the LMB breached, when the discharge in the River Indus was approaching 1,085,000 cusecs, contradicted the factual position, as noted in the Judicial Flood Inquiry Tribunal (2010). The Tribunal and UET Commission's main focus remained how the LMB breached; rather they had investigated the causes for extraordinary head up, which may be the cause of breach of LMB. 
Sci. Technol. Dev., 35 (1): 1-5, 2016

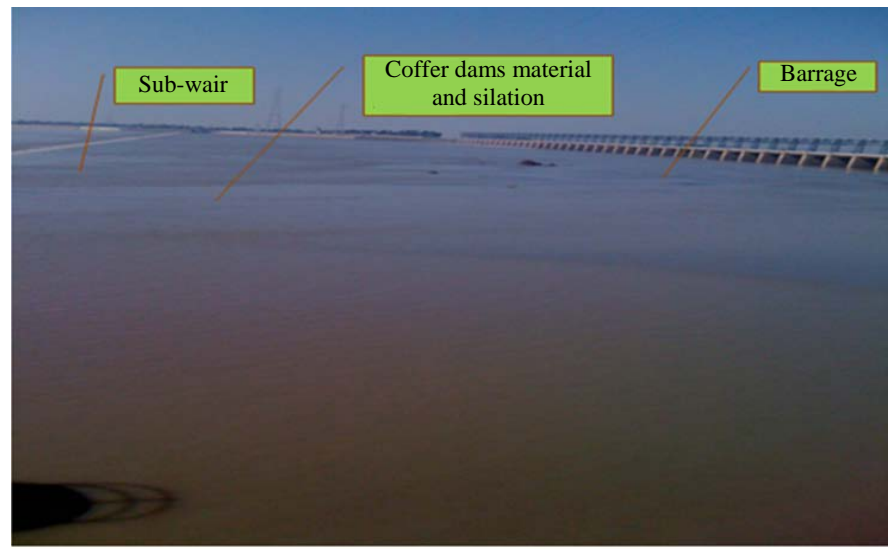

Fig. 1: Material of coffer dams and siltation

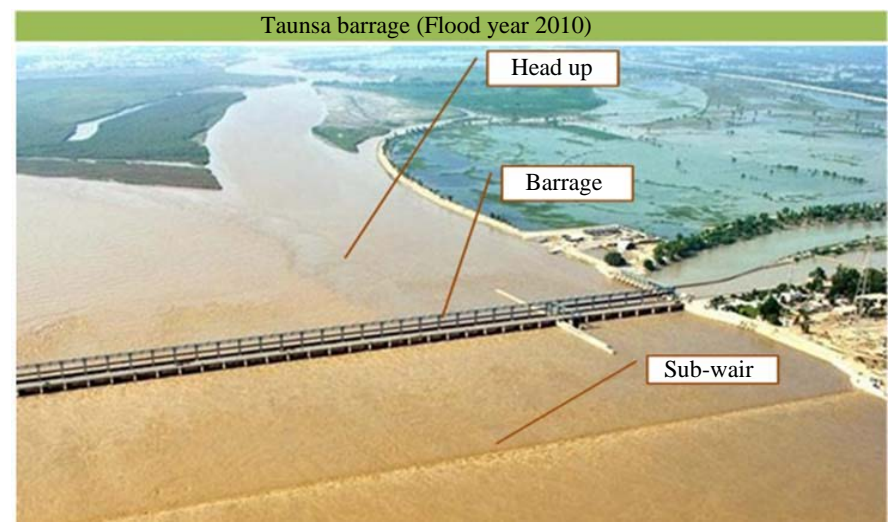

Fig. 2: Sub-weir developed confinement and head up (Flood 2010)

During the years 2005-08, this very important diversion structure has been remodeled in the name of its rehabilitation and modernization, by spending more than 11 billion rupees borrowed from the World Bank (Chaudary and Sarwar, 2014). As stated earlier, an $8 \mathrm{ft}$ high sub-weir/wall was constructed at about $900 \mathrm{ft}$ distance downstream of the barrage. Moreover, massive coffer dams were constructed to carry out the construction works of sub-weir and remodeling of the stilling basin. The leftover material of coffer dams still lying up to the crest level of sub-weir had developed a reverse slope downstream of the barrage (Fig. 1). A snap of barrage (Fig. 2), taken during flood year 2010, showed that the river course on downstream of the barrage was blocked and the water level upstream and downstream of the barrage had almost the same.

The model study report (IRI., 2005) of Taunsa barrage rehabilitation/remodeling noted that the existing tail water level at the discharge of 1,000,000 cusec was EL 433.40. The water level attained at the physical model upstream of the sub-weir was EL 440.5, whereas the water level upstream of the barrage was EL 446.00. Figure 2 clearly shows that the water level upstream and downstream of the barrage became almost the same during flood year 2010. The level difference of $5.50 \mathrm{ft}$. (EL 446.0-440.50) and 7.10 ft (EL 440.5-EL 433.40) envisaged by the designers of the rehabilitation project may not have any logical grounds. Moreover, the crest level of barrage under-sluices (EL 425) was almost the same as of the sub-weir (EL 424), which had developed channel flow through under-sluices; consequently, the discharge capacity of the barrage got reduced.

\section{DISCHARGE CAPACITY AND FLOOD LEVELS}

The Tribunal Report noted that the water level near the breached section was RL 459.8, whereas in the past, the level never increased to RL 452.0. The increase in water level/head appears to be the main cause for the collapse of LMB. Moreover, the pond level at the time of breach was RL 446.8. A $13 \mathrm{ft}$ drop in water level from barrage (RD $0+000$ ) to $\mathrm{RD} 32+000$ seems unrealistic. If 
a consistent drop in water level is assumed, then water level at the barrage may be about RL 446.8+(RL 559.8-RL 452.0) = RL 454.8.

After the construction of sub-weir, the discharge capacity of Taunsa barrage may have been compromised (Chaudary and Sarwar, 2014). The PID (2011) noted that the capacity of the Jinnah barrage shall be reduced from 950,000 cusecs to 850,000 cusecs if $6 \mathrm{ft}$ high sub-weir is placed $\mathrm{d} / \mathrm{s}$ of the barrage. On the basis of the above said facts, the capacity of Taunsa barrage may be established by some independent forum.

\section{CONCLUSION}

This research study emphasized that remodeled Taunsa barrage is hydraulically different as compared to the barrage before its remodeling. The cause of LMB collapse may be the extraordinary rise in water; whereas extraordinary head up could be due to $8 \mathrm{ft}$ high sub-weir constructed downstream of the barrage and left over material of coffer dams along with few partially closed gates. The Irrigation Department may constitute a team of hydraulic experts to revisit reasons for head up so that such catastrophe can be avoided in future.

\section{REFERENCES}

Chaudary, Z.A., 2009a. Hydraulic/structural deficiencies at the Taunsa Barrage. Pak. J. Sci., 61: 135-140.
Chaudary, Z.A., 2009b. Punjab barrages-hydraulic deficiencies and rehabilitation solutions. Pak. J. Water Resour., 13: 29-36.

Chaudary, Z.A., 2010a. The Jinnah Barrage rehabilitation project-prospects and concerns. J. Dam Eng., 19(3).

Chaudary, Z.A., 2010b. Surface flow hydraulics of Taunsa barrage: Before and after rehabilitation. Pak. J. Sci., 62: 116-119.

Chaudary, Z.A., 2010c. Performance assessment of Taunsa barrage subsidiary weir for long term rehabilitation planning. Pak. J. Eng. Appl. Sci., 7: 65-70.

Chaudary, Z.A. and M.K. Sarwar, 2014. Rehabilitated Taunsa Barrage: Prospects and concerns. Sci. Technol. Dev., 33: 127-131.

IRI., 2005. Punjab barrages rehabilitation project: Sectional model study of Taunsa Barrage 1172. Irrigation Research Institute (IRI), Irrigation.

Judicial Flood Inquiry Tribunal, 2010. Causes of major breaches in River Indus during the exceptionally high flood of 2010. Judicial Flood Inquiry Tribunal, High Court, Lahore, Pakistan.

PID., 2007. Taunsa barrage emergency rehabilitation and modernization project. Design Report, Punjab Irrigation Department (PID), Lahore, Pakistan.

PID., 2011. Comments on proposed subsidiary weir at Jinnah Barrage. Central Design Office, Punjab Irrigation Department (PID), Lahore, Pakistan. 